\title{
Competitive Dynamic between Individual Behaviors of the Mass Media Industry
}

\author{
Yogi Yunanto $^{1}$, Fendy Suhariadi ${ }^{2}$ and Praptini Yulianti ${ }^{3}$ \\ ${ }^{1,3}$ Fakultas Business Economics, Airlangga University, Surabaya-Indonesia \\ ${ }^{2}$ Fakultas Psychology, Airlangga University, Surabaya-Indonesia \\ yogi.yunanto-2017@feb.unair.ac.id
}

\begin{tabular}{|l|}
\hline \\
\hline
\end{tabular}

\begin{abstract}
Competitive behavior is also a major factor in the competitive media industry is now getting very tight. This is caused by the print media competition with online or Internet-based media in getting news and advertising to attract participants from readers. This research method uses historical depth case study intended to produce an institutional explanation of the characteristics of the typical behavior shown by principal component analysis. The study also incorporates the classical approach to the historical focus on qualitative interpretation of data, In order to survive, the print media should be able to maintain the credibility and public trust on the information presented is now more attractive and more accurate. The print media began to be threatened because of the rapid development of emerging online media via internet access has encouraged people to seek to access online media simply and easily via mobile phones or gadgets. Connoisseurs of the print media loyal readers will turn to online news media. Reality has happened would threaten the print media industry, but the print media already have the characteristics of the first, namely: the news that is always clear, complete and detailed, online media faster and more sophisticated to broadcast news and always up to date but the online news can only be enjoyed by using the sophisticated tool not all communities have the tools and not all people can use sophisticated technology to always follow the news online.
\end{abstract}

Keywords: Competitive dynamics, the mass media industry, technology

\section{INTRODUCTION}

Nowdays, competitive in some aspects both in business affair and education had been a characteristic of certain agency. Research in the field of strategic management has improved several perspectives in understanding the competition, such as industry organizations (M, 1996), Which is based resource (Wernerfelt, 1984) dynamic capability perspective (Teece, Pisano, \& Shuen, 1997) and competitive dynamics (Smith \& Barclay, 1999), In the perspective of the dynamics of competitive dynamics that stand out from the rest is seeing competition as the interaction between the organization contenders (Smith, Curtis \& Grimm, 1991), The question is how to understand the process that generates the competitive behavior of organizations and results are given. According to the previous dynamic competitive research, the process of formation of the competitive behavior of individuals not only involves intention and cognition manager (Chen, 1995) but also the use of existing capabilities (Ndofor, Sirmon, \& He, 2011), These two elements are combined in the framework of awareness-motivation-capability (AMC) (Chen $\& \mathrm{Su}, 2007)$, The tradition of the dynamics of competition has been widely adopted as the main theoretical perspectives to use theory and predict competitive behavior.

According to the AMC framework, to initiate a competitive action of an organization, decision-makers must be the first to recognize the opportunity to perform certain actions and 
then be motivated to perform an action (Williams \& Williams, 2007), Finally, the organization as a whole must have the ability to take action even though not all studies on the competitive behavior of companies explicitly use the framework of the AMC, largely contribute in managerial decision making (A and $\mathrm{M}$ ) and the ability to direct the organization's competitive behavior and competitive performance (Lamberg, 2016).

An alternative approach proposed by the (Lamberg, 2016) rooted in the new institutional economic (NIE), which saw economic behavior that is determined by the rules and institutions that have organizational governance (Williamson, 2000), Although there are some exceptions (Livengood \& Reger, 2010) action-based literature on competitive strategy has regarded the competition as a reaction to events in the market environment directly, thus excluding the possibility of action that can happen is interpreted to reflect the institutional environment companies are already embedded (Zenger, et al, 2000), It was the most prominent exception to this dominant view is the recognition of conformity typical behavior in an industry, with a 'continuation of tradition' and 'industry experience' as a contributing factor (Chen \& Miller, 2012).

Competitive behavior is also a major factor in the competitive media industry is now getting very tight. As this becomes more intense competition caused by the print media to online or internet-based media will get news ads that will attract the sympathy of the reader. In the last four years it is known that people who access the print media has declined, this can be seen in the table below.

Table 1

The population aged 10 years and above and who have access to the mass media (\%)

\begin{tabular}{ccccc}
\hline Indicator & 2003 & 2006 & 2009 & 2012 \\
\hline Hearing Radio & 50.30 & 40.27 & $23: 51$ & $18: 58$ \\
$\begin{array}{c}\text { Watching } \\
\text { television }\end{array}$ & 84.95 & 85.87 & 90.28 & 91.69 \\
$\begin{array}{c}\text { Reading } \\
\text { Newspaper/ } \\
\text { Magazine }\end{array}$ & 23.71 & $23: 47$ & 18.95 & 17.67 \\
\hline
\end{tabular}

source: (BPS, 2015)

As presented in Table 1 above, the population aged 10 years and above and who have read the print media (newspapers / magazines) actually continued to decline since 2010 until 2019. In fact, the survey results (Livengood \& Reger, 2010) show that in 2012 neutralizing the newspapers fell by $13.3 \%$. However, they are accessing online or watching television instead it showed a rising trend.

This kind of condition is to be a threat but also an opportunity for the print media Jawa Pos and Kompas which today has become the leader of the print media market. This is evidenced by (Mantzavinos \& North, 2004) Consumer \& Media View (CMV) published the results of the third quarter of 2017. The survey of Jawa Pos ranked first category Top Daily Newspapers. Jawa Pos has a reading level reaches 842000 readers. The second order is a compass with a readership of 751,000 .

Although Indonesia has entered the digital era, the newspaper will still have a strong position in society (Williams \& Williams, 2007), Jawa Pos has undertaken a substantial program for many years and have a very high commitment to success in cooperating with talented young people, either through newspapers or through the pages print off activities, such as detection program (Mantzavinos \& North, 2004), Namely the attempt to detect a strategy that is complete to find the target, cooperation, and retain loyal readers hobby. In 2010, Jawa Pos create brand activity detection in the form of the basketball competition at the high school level Surabaya. The young child's response is quite large. This is the forerunner to the DBL Development Basket League (DBL) which is famous today. In fact, after the success with the detection, Jawa Pos create pages targeting the community For Her young woman urban and Life Begin at 50 that target mature adult community (North, 1994).

The purpose of this study is to provide an institutional explanation for the behavior patterns of historical contingency. We build our theorizing on comparative setting in which we observe the competitive action of two different companies: the Jawa Pos behavior "strategy as an option" (M, 1996) specifically for the print media have diverse market segments of circles and a compass that shows a totally different behavior in terms of the level of mastery of the media industry. In line with the work (Carden, 2013), Then the problem researchnya is what economic problems faced by Java Post by acting in the market and what 
is not in accordance with their institutional environment that explains the behavior of their competition we explain the reasons that drive strategic decisions and development capabilities as interplays of path dependence (Pierson, 2000) at three levels: informal institutions, which regulate the structure of the transaction, and the sharing of knowledge among the industry elite.

Competitive dynamics research continues with theoretical ideas about the relationship between processes that drive competitive behavior and institutional and historical context in which the actions of the company embedded (Chen \& Miller, 2012), As a result, the mechanisms underlying the associations were identified between the different variables remain largely implicit. According to (Chen, 2012) a path that can be moved forward in this case will affect communication theory-oriented theory, which has a well-established tradition of expressing economically embedded behavioral phenomena mechanically. Until recently, the idea of institutional strategies for action based competition basically improve people's behavior in accordance with the existing industry norm, which is 'average' competitive behavior (Podolny, 1993).

Some of the competitive dynamics literature focuses on micro-economic transactions and significance relationship between the organization and the surrounding institutional environment, a perspective that is informed by the NIE will change this setting in reverse. New Institutional Economics saw competitive action as a 'third energy savings (Williamson, 2000) or 'strategy' (Williamson, 1991), which is determined by the first-order and second order are set, namely, formal and informal institutions and governance structures. The position of competitive action this as a specific layer within a larger institutional system questioned many explicit and implicit assumptions regarding the decision-making criteria in the competitive dynamics literature and has the potential substantially theoretically strengthen the literature. The model of our institutional processes that lead to a very clear context of competition, mainly triggered by (Williamson, 2000) and (North, 1994) see also (Greif, 1993), The main element is a model of competitive action which is embedded in an institutional context and the specific governance structure, on the one hand, and restrictions on these effects by companies that suit their operations on the other side (Greif \& Laitin, 2004).

The first difference between the dynamics of competition and rationality regarding the NIE literature in general and in particular the definition of exchange problems. In the literature of the dynamics of competition, problems that encourage efforts to remain in the market directly: the need to maximize short -term profits relative market that benefit the competitors compete with the same customers (Williams \& Williams, 2007), Typically, the purpose of such behavior is operationalized in terms of market share (Ketchen, Snow, \& Hoover, 2004), On the one hand, the company's main goal is to be minimalize adverse response against their own actions. On the other hand, this destination is assumed involve defense against losing one's market position in the face of the threat of peer action. Thus, the key trigger for the competitive action is maximization (implicit) of the company's share of the customer's purchase and sometimes requires the ability to get financial management capability (Williamson, 1991).

NIE literature took a substantially different attitude about rationality and managerial cognition. Such that (Langlois, 2013) summarized in his review of the book (Carden, 2013), NIE trying to explain the puzzle is in response to the charges, limitations, and scarcity faced by economic actors. 'Therefore, from the perspective of NIE, organizational actors - entrepreneurs, managers, and others - observe and interpret the institutional environment and contracts that guide the actions and act accordingly (Silverman, 2016), according to (Mantzavinos \& North, 2004) a further emphasis on recognition and blasphemy (Robertson \& Langlois, 1994) as the appropriate mechanism to ensure better behavior than others. Mental model is a cognitive tool 'in the sense that the actor considers institutional and environmental elements in their contracts related to economic transactions that result in, for example, decisions regarding competitive behavior (Teece et al., 1997).

Literature competitive dynamic was very attentive to the specific nature of the corporate governance structure. Environmental contract company is considered primarily transactional space between competing companies, their customers (Williams \& Williams, 2007), And sometimes suppliers of resources (Eliram \& Tate, 2013); Individual studies focus on the differences between companies (Chen, 1995) and cooperative relationship between them (Gnyawali \& Madhavan, 2001), For example, it has been found that the implicit social contract (ie, mutual understanding) ( $\mathrm{Yu}$ \& 
Subramaniam, 2009) there between rival associated with which market belongs to whom (and to what extent). The overall picture, however, remains centered on the company without explicitly including environment variables that affect the contract as their competitive behavior.

The literature assumes that the competitive dynamic to test particular characteristics, specific abilities that qualify (Chen, 2012), Typically, this capability is considered to be the aggregate of the various types of capabilities without particular distinction between them. Therefore, the dynamic competitive literature, for example, does not explain the difference between the technological capabilities and other capabilities. Usually, the only thing different is the ability of top management cognitive ability to process (detecting and interpreting) and transforming information into the appropriate action (Williams \& Williams, 2007) although this capability is implicitly captured by the notion of awareness and motivation within the framework of the $\mathrm{AMC}$ and consequently disconnected from the ability to 'actual' (Hambrick \& Cho, 1996), Therefore, and in connection with the source of simplicity and competitive inertia, for researchers dynamics of core competition, the lack of ability is a good enough cause for inaction competitive. In general, the basic competencies that can be received from the ability to understand (Lamberg, 2016) is that the company acquire new abilities to develop skills and knowledge in or seeking new complementary capabilities or beyond the boundaries of the firm, such as mergers and acquisitions. In both cases, a history of the highest decision estimate that there are possible actions competitive rivalry (Winter, 2006),

\section{METHOD}

The mass media industry changed substantially during this period of two decades. These changes caused by globalization and new technology innovation. In this study, the mass media industry to work naturally with print media companies which first competitive action we compare with Kompas effectively represent the largest national newspapers. In this analysis, the authors provide an institutional explanation of the typical characteristics of Jawa Pos.

Our data collection process is divided into four phases that produce data that is not systematic and investment and divestment decisions made by the company under investigation. Our data is different from the dynamics of the first wave of empirical studies, (Smith, Curtis \& Grimm, 1991), First, the authors do triangulation any identification using data from sources studied. Second, the authors tested a number of strategic actions that make sense by each company.

The method in this study using historical depth case studies (Jacobides, 2005) which is intended to generate an institutional explanation of the characteristics of the typical behavior shown by principal component analysis. The study also combines the classical approach with historical Data (Carr, 1966) focusing on the qualitative interpretation of the competitive action that can be tracked and reconstructed using multiple data items so as to maximize the interpretation of interpreters researchers (Bryant, 1994),

\section{RESULTS AND DISCUSSION}

At the beginning of the third millennial's today, experts in the field of communication technology experts will revealed that there will be changes in the type of mass communication media industry, and will be affected to the emergence of a new mass media industry that is increasingly sophisticated (Williams \& Williams, 2007), The volume of increasingly sophisticated news messages and also the greater capacity and speeds up to date is also growing fast and accurate, this sort of thing will be the actuality and the closeness of the messages to the recipients in the all over world (proximity) will also be higher. This approach is also to include geographic proximity, closeness sociological, cultural proximity, and psychological closeness between the media industry with the audience (Lamberg, 2016) Based on the reality we now live in an age of technological sophistication advances Modern information would cause an explosion occurrence of major changes to the information in the life of mankind today throughout the world. We have experienced where the transition from industrial society is now the revolution of the information society, currently the most important part of human life be it individual, organization or institution, the online media that have sprung up will be supported by technology that will present very much on the news up to date (Langlois, 1985),

In Indonesia, the arrival of online media will not shift the print media, it reinforces the print media. Because it is both possessed characteristics that are very different online news deliver fast and short, accurate (Langlois, 
2013), While news such as newspapers or newspapers tell the story as a contextual and depth to hypnotize readers, in the event of an incident such as the current print media will be trying to convey in more detail starting from the beginning of the incident, the cause until the measures have been carried out in order to cope with the incident (Chen \& Miller, 2012).

Even among the print and online media will synergize to deliver information more complete and diverse and rich information up to date for the mass media has a concept of providing news and different deliver (Williamson, 2000), In answer to the target audience needs that must be met, then the print media will still be able to maintain in because having segmentation particular of the online media that can reach all of the mass of the lower classes, medium to the upper of the evidence there can be conclude following which the print media industry can survive given the need for the reader's interest more accurate information and in-depth (Langlois, 2013),

Designing online media to create a print newspapers that have been published to the modern digital version. Press company already implements many such tactics one compass, loyal customers or readers who have subscribed to buy a print newspaper is now able to directly access the sam edition newspaper digital version or E-paper (North, 1994), Notably its online by means scan the barcode that has been printed on the printing paper while also subscribers or readers can also enjoy access to facilities newspapers and newspaper afternoon extra edition if it does have a print newspapers at the same time or day. Consider reducing the amount of circulation of the print media to make another answer to defend (Williams \& Williams, 2007),

\section{CONCLUSION}

The print media began to be threatened because of the rapid development of emerging online media via internet access has encouraged people to seek to access online media simply and easily via mobile phones or gadgets. Connoisseurs of the print media loyal readers will turn to online media (Carden, 2013), Reality has happened would threaten the print media industry, but the print media already have the characteristics of the first, namely: the news that is always clear, complete and detailed, online media faster and more sophisticated to broadcast news and always up to date but the online news can only be enjoyed by using the sophisticated tool not all communities have the tools and not all people can use the technology to always follow sophisticated online news (Chen, 2012)

Technological advances in the media industry to change the real state of 180 degrees in the field, with a very low cost and affordable every internet user now can basically create their own media more pitch up to date they could carry out such work all the functions of journalism itself (North, 1994), Began to prepare plans to write the results reporting coverage, edit it'll be interesting and contain up to start spreading the word that has been ready to various internet sites or web blogs are available for free access.

Thus the practical work can be done anytime and anywhere that everyone who has access to the internet then it can be said with impromptu journalists despite the resulting quality is still doubted (Chen \& Miller, 2012).

To still be able to survive the print media should be able to maintain credibility and confidence in the information that has been presented (Williams \& Williams, 2007), Reputation, credibility and public confidence will be built by the spirit of professionalism that ethical journalism is journalists provide information factual dish properly verified. Bids for the print media can survive (Teece et al., 1997) said that if the print media to survive it must change if it does not want eliminated, one of which must be pursuing a strategy that must be implemented print media order to survive. Now the print media if they want to survive must change the form of newspaper media into electronic media

\section{REFERENCES}

BPS. (2015). https://www.bps.go.id/subject/13/ keuangan.html\#subjekViewTab3.

Bryant, J. M. (1994). Evidence and Explanation in History and Sociology: Critical Reflections on Goldthorpe 's Critique of Historical Sociology. The British Journal OfSociology, 45(1), 3-19. Retrieved from https:// www.jstor.org/stable/pdf/591521.pdf?seq=1

Carden, A., \& Allen, D. W. (2013). The institutional revolution : measurement $\&$ the economic emergence of the modern. The University of Chicago Press, 14, 267. https://doi.org/10.1007/s11127-012-0029-7

Carr, E. H. (1966). What is history? Foundations of a Planned Economy, 1, 157-185.

Chen, G., \& Hambrik, D. C (2012). CEO Replacement in Turnaround Situations: Executive ( Mis ) Fit and Its Performance Implications CEO Replacement in Turnaround Situations: Executive ( Mis ) 


Fit and Its Performance Implications.
Organization Science Publication, 23(1),
225-243. Retrieved from https://
doi.org/10.1287/orsc.1100.0629

Chen, M. J., \& Hambrik, D. C. (1995). Speed , Stealth, And Selective Attack: How Small Firms Differ From Large Firms In Competitive Behavior. The Academy of Management Journal, 38(2), 453-482. Retrieved from https://www.jstor.org/ stable $/ 256688 ?$ seq $=1$

Chen, M., \& Miller, D. (2012). Competitive Dynamics. The Academy of Management Annals, 6(1), 135-210. https:// doi.org/10.1080/19416520.2012.660762

Chen, M. J., Su, K, H., \& Tsai, W. (2007). Competitive Tension: The AwarenessMotivation-Capability Perspective. Academy of Management Journal, 50(1), 101-118. Retrieved from http:// homepage.ntu.edu.tw/ khsu/vita/amj.pdf

Gnyawali, D. R., \& Madhavan, R. (2001). Cooperative Networks And Competitive Dynamics: A Structural Embeddedness Perspective. Academy of Management, 26 (3), 431-445. Retrieved from https:// www.jstor.org/stable/259186? seq $=1$

Eliram, L. M., Tate, W. L., \& Feitzinger, E. G. (2013). Factor-Market Rivalry And Competition For Supply Chain Resources. Journal of Supply Chain Management Resources, 49, 29-46. Retrieved from https://doi.org/10.1111/jscm.12001

Greif, A. (1993). Contract Enforceability and Economic Institutions in Early Trade: The Maghribi Traders' Coalition. The American Economic Review, 83(3), 525-548. Retrieved from https://www.jstor.org/ stable/2117532?seq $=1$

Greif, A., \& Laitin, D. D. (2004). A Theory of Endogenous Institutional Change. American Political Science Review, 98(4), 633-652. Retrieved from https://doi.org/10.1017/ S0003055404041395

Hambrick, D. C., Cho, T. S., \& Chen, M. J (1996). The Influence of Top Management Team Heterogeneity on Firms' Competitive Moves. Administrative Science Quarterly, 41(4), 659-684. Retrieved from https:// doi.org/10.2307/2393871

Ingram, P., \& Silverman, B. (2016). The New Institutionalism in Strategic Management. Advances in Strategic Management. 19, 130. Retrieved from https:// www.researchgate.net/ publication/279931264 The New Institutio nalism_in_Strategic_Management_Advance s_in_Strategic_Management_Vol_19

Jacobides, M. G. (2005). Industry Change Through Vertical Disintegration: How And Why Markets Emerged In Mortgage Banking. Academy of Management Journal, 48(3), 465-498. Retrieved from https:// pdfs.semanticscholar.org/8744/ a0f0ec40a5243458f2604fe70f5b68c3629c.p df

Ketchen, D. J., Snow, C. C., \& Hoover, V. L. (2004). Research on Competitive Dynamics: Recent Accomplishments and Future Challenges. Journal of Management, 30(6), 779-804. https://doi.org/10.1016/ j.jm.2004.06.002

Lamberg, J. Laurila, J., \& Nokelainen, T. (2016). Institutional Path Dependence in Competitive Dynamics: The Case of Paper Industries in Finland and the USA. Managerial And Decision Economics, 1-21. https://doi.org/10.1002/mde.2839

Langlois, R. N. (1985). Rationality , institutions , and explanation. Cambridge: Cambridge University. Retrieved from https://richardlanglois.uconn.edu/wp-content/uploads/ sites/1617/2019/09/RIE.pdf

Langlois, R. N. (2013). The Institutional Revolution: A review essay, 26, 383-395. https://doi.org/10.1007/s11138-013-0237-5

Livengood, R. S., \& Reger, R. K. (2010). That' S Our Turf! Identity Domains And Competitive Dynamics. Academy of Management Review, 35(1), 48-66. Retrieved from https://doi.org/10.5465/ amr.35.1.zok48

Mantzavinos, C., North, D. C., \& Shariq, S. (2004). Learning, Institutions, and Economic Performance. Learning, Institutions, and Economic Performance Learning, 2(2), 7584. Retrieved from https://doi.org/10.1017/ S1537592704000635

Ndofor, H. A., Sirmon, D. G., \& He, X. (2011). Firm Resources, Competitive Actions And Performance: Investigating A Mediated Model With Evidence From The In-Vitro Diagnostics Industry. Strategic Management Journal, 32, 640-657. https:// doi.org/10.1002/smj

Denzau, A. T., \& North, D. C. (1994). Shared Mental Models : Ideologies and Institutions. KYKLOS: International Review for Social Sciene, 47(1), 3-31. Retrieved from https:// doi.org/10.1111/j.14676435.1994.tb02246.x

Pierson, P. (2000). Increasing Returns, Path Dependence and the Study of Politics. The American Political Science Review, 94(2), 251-267. Retrieved from https:// www.jstor.org/stable/2586011?seq $=1$

Podolny, J. M. (1993). A Status-based Competition Model of Market Competition. The American Journal of Sociology, 98(4), 829872. Retrieved from https:// www.gsb.stanford.edu/faculty-research/ working-papers/status-based-model-marketcompetition

Porter, M. E. (1996). What is Strategy. Harvard Business Review, 74(6), 61-78. Retrieved from https://hbr.org/1996/11/what-is- 
strategy

Robertson, P. L., \& Langlois, R. N. (1994). Institutions, Inertia and Changing Industrial Leadership. University of Victoria, 8(6), 359 -378. Retrieved from https:// doi.org/10.1093/icc/3.2.359

Smith, K. G., Grimm, C. M., Gannon, M. J., \& Chen, M. J. (1991). Organizational Information Processing, Competitive Responses and Performance In The US . Domestic Airline Industry. Academy of Management Journal, 34(1), 60-85. Retrieved from https://www.jstor.org/ stable $/ 256302$ ?seq $=1$

Smith, J. B., \& Barclay, D. W. (1999). Selling partner relationships: The role of interdependence and relative influence. The Journal of Personal Selling and Sales Management, 19(4), 21-40. https:// doi.org/10.1006/jasc.1997.0217

Teece, D. J., Pisano, G., \& Shuen, A. (1997). Dynamic Capabilities and Strategic Management. Strategic Management Journal, 18(7), 509-533. Retrieved from https://onlinelibrary.wiley.com/doi/ pdf $/ 10.1002 / \% 28$ SICI $\% 291097-0266 \%$ $28199708 \% 2918 \% 3 \mathrm{~A} 7 \% 3 \mathrm{C} 509 \% 3 \mathrm{~A} \%$ 3AAID-SMJ882\%3E3.0.CO\%3B2-Z

Wernerfelt, B. (1984). A Resource-based View of the Firm. Strategic Management Journal, 5 (2), 171-180. Retrieved from http:// web.mit.edu/bwerner/www/papers/ AResource-BasedViewoftheFirm.pdf

Williams, S. D., \& Williams, S. D. (2007). Gaining and losing market share and returns: a competitive dynamics model Gaining and losing market share and returns: a competitive dynamics model. Journal of Strategic Marketing ISSN:, 15, 139-148. https://doi.org/10.1080/09652540701321033

Williamson, O. E. (1991). Strategizeng, Economizing, and Aconomic Organization. Strategic Maiaagemnent Journal, 12, 75-94. Retrieved from https://doi.org/10.1002/ smj.4250121007

Williamson, O. E. (2000). The New Taking Institutional Economics: Taking Stock, Looking Ahead. Journal of Economic Literature, 38(3), 595-613. Retrieved from https://www.jstor.org/stable/2565421?seq=1

Winter, S. G. (2006). Toward A NeoSchumpeterian Theory Of The Firm. Deloitte and Touche Professor of Management, 7(3), 1-20. Retrieved from https://doi.org/10.1093/icc/dtj006

Yu, T., \& Subramaniam, M. (2009). Rivalry Deterrence In International Markets : Contingencies Governing The Mutual Forbearance Hypothesis. Academy of Management Journal, 52(1), 127-147. Retrieved from https:// asu.pure.elsevier.com/en/publications/ rivalry-deterrence-in-international-markets- contingencies-governi

Zenger, T., Lazzarini, S. \& Poppo, L. (2000), "Informal and formal organization in new institutional economics", Ingram, P. and Silverman, B. (Ed.) The New Institutionalism in Strategic Management (Advances in Strategic Management, Vol. 19), Emerald Group Publishing Limited, Bingley, pp. 277-305. https:/ doi.org/10.1016/S0742-3322(02)19009-7 